\title{
Guardianship: Parental Communication and Students Participation in School Activities
}

\author{
Jerald C. Moneva \\ Department of Education-Mandaue City Division \\ Mandaue City, Cebu, Philippines \\ Tel: +63908-927-3038Ｅ-mail: freezingfire1979@gmail.com \\ Crischel Jean M. Bago \\ Jagobiao National High School \\ Mandaue City, Cebu, Philippines \\ Tel: +63955-965-0729Ｅ-mail: crischeljean@gmail.com
}

\author{
Sheila T. Ycong \\ Cebu City, Philippines \\ Tel: +63942-082-0293Ｅ-mail: sheila.ycong001@deped.gov.ph
}

Received: February 10, 2020 Accepted: March 20, $2020 \quad$ Published: April 2, 2020

doi:10.5296/ijssr.v8i2.16791ＵRL: http://dx.doi.org/10.5296/ijssr.v8i2.16791

\begin{abstract}
In the current scenario, parent child communication has been becoming vague. Usually, students are focused on their phone while at home, while their parents are too busy at work. Parental communication is the communication between a parent and a child. Having communication and stronger relationship of the family is very important, it can have an impact on the family's closeness and can improve students participation. The study used checklist-questionnaire in gathering the data. In getting results, the study used chi-square and weighted mean to examine the relationship between the two variables. . There were two hundred forty five respondents that were gathered in Senior High School of Jagobiao National High School in North road, Jagobiao Mandaue City. The results showed that there was a relationship between parental communication and students participation in school
\end{abstract}




\section{Macrothink

activities. The parents should communicate to their children and encourage them to participate school activities. It can improve their performance and grades in school. The communication given by their parents can make the students more confident to join and participate the school activities.

Keywords: parental, communication,school activities, student participation 


\section{Introduction}

\subsection{Rationale}

All students need a parental communication to have energy to participate in school activities. Parents who communicate effectively with their children are more likely to participate in school activities. Parents need to spend time with their children to have an appetite and encourage to their children to participate in school activities. Relationship between parents and their children are greatly improve when there is effective communication taking place.

Communication is a dealing with other people. Good communication skills will be good or helpful for every people. Having a communication there will be effectively relationship. It is very important for parents to be able communicate openly and effectively with their children. Parents participation in school activities has been one of the most important to support and give time to communicate their children to have an energy to participate in school activities. Students are too focused with cellular phones gradually replacing traditional communication of parent and child with digital communication.

Parents who communicate effectively with their children are more likely to have children who are willing to do what they are told. Such children know what to expect from their parents. Once children know what is expected of them, they are more likely to live up to these expectations (Zolten \& Long, 2006). Parents and teachers communicate well with one another to support their students together. As such, communication between home and school is vital (Merkley, Schrimdt, Dirksen, \& Futiler, 2006). Parents communication with their children during adolescence can give more attention (Laursen, 2014) .

The researcher intends to know if the participation of students in school and the parental communication of the students whether the two have correlation.

\section{2 Theoretical Background}

This study is supported by Koerner and Schrodt Family Communication Patterns Theory, proposed by Koerner and Schrodt in 2014. Koerner and Schrodt study the theory about family communication patterns theory. This theory explain that the family communication patterns emerge from the process of co-orientation, without which human communication would not be possible. (Koerner \& Schrodt 2014).

Parents who have a good communication to their children can give encouragement to participate in school activities. Parents must give attention to their children even though they are busy, because they can give the students a comfortable feeling to open up everything, love, support and give time to their children encourage to participate in school activities.

Students who encourage their parents to participate the school activities. The students get that from the comfortable feeling to open up everything, love, support and time that give their parents. The students depends on how their parents interact them. Parents and students have a good communication their relationship must good too.

Even the parents and their children are busy as long as they have communication the students 
still encourage to participate in school activities. The theory of Koerner and Schrodt has a relationship between parental communication and students participation in school activities that talks about on how they emerge of co-orientation and communicate that can give to the students comfortable feeling to open up everything, love, support and time that give their parents to their children.

\subsection{Statement of Purpose}

The study intends to know the level of extent participation in school activities, then the level of parental communication of the students, assess there is a relationship between students participation in school activities.

\subsection{Review of Related Literature}

The study parental communication and students participation in school activities have been supported by the different articles and it serve as the basis of the study.

The relationship between parents and children have an important relationship (Runcan, Constantineanu, \& Popa, 2012). Teenagers who communicate better to their parents are less likely to engage in sexual activities (Karofsky, Zeng, \& Kosorok, 2001). To improve the communication of adolescent to their parents through health care should include adult fashion (Marcell, Ford, Pleck, \& Sonenstein, 2019). Parents communication with their children during adolescence can give more attention (Laursen, 2014). Parents communicate their children effectively the children are more motivate to do what the parents say and the children do their best to cope up the expectations of their parents (Zolten \& Long, 2006). When it comes family communication it is very helpful to us to communicate each other and it have a positive results of the family communication ( Le Poire, 2019).

Furthermore, Parental communication can contribute aggressiveness relationships to their children (Eustice, 2000). Parental interaction in sport can have a huge impact on children, so a better understanding of this aim is required to produce the best developmental results that sport can achieve (Grimm, Dunn, Hall, \& Dorsch, 2017). Having a communication to the family can have a potential to understand other people towards their attitude in the society as a whole (Koerner \& Schrodt, 2014). The communication and relationship of parents and their children are the most important of individuals life to show affection, make sense of their life experience and create communication surroundings (Horstman, Hays, \& Maliski, 2016).

Those children belong to high oriented family is more motivated to act of what their parents expected and have a capability to talk through easily (Thorson \& Horstman, 2016).Parents and their children have enough time to discuss the lesson about the another half of the workbook though its presented eight vignettes about different problems on how children handle the problems (Irwin 2002). Family communication is the most strong foundation to understand, how the family communication is important (Koerner \& Fitzpatrick, 2002). Parents have low communication to their child are correlated more to the behaviour of the adolescents (Davidson \& Cardemil, 2009). Parents and teachers can communicate each other to support the students either school and home (Merkley, Schrimdt, Dirksen, \& Futiler, 2006). 


\section{Ml Macrothink}

International Journal of Social Science Research

ISSN 2327-5510

2020, Vol. 8, No. 2

To maintain the partnership activities of both teachers and the other faculty members can have a good benefits of their students (Lachance, Benton, \& Klein, 2007). To help develop students skills and personalities so as to prepare them for more advanced levels through school-based activities (Petra, 2014). The characteristics of teachers and students ' behavior is important role in developing student participation (Aziz, Quraishi, \& Kazi, 2018). Participation of students in the classroom is an important part of the learning and teaching process that promotes quality of education (Debele, 2017). In order to the students participation It is needed to encourage and create safe environment (Qing-he, 2016).

Learning is an immersive process involving participation of both lecturers and the students (Abdullah, Bakar \& Mahbob, 2012). The characteristics of teachers and students' behavior is important role in developing student participation (Aziz, Quraishi, \& Kazi, 2018). Participation is important not only in health promotion, but also because it gives capability both health and education of the students (Griebler, Rojatz, Simovska, \& Forster, 2014). Through student participation in school is necessary have a meaningful learning (Simovska, 2004). Students and staffs with improvement in student engagement participation provide more particular guidance for school programs (Grogan, Henrich, \& Malikina, 2014).

Students have a deep understanding of student participation and it depends on the expectation and responsibilities of students and teachers (Bergmark \& Westman, 2018). The teacher must create helpful learning situation so that the students will actively participate (Abdullah, Bakar, \& Mahbob, 2012). Participation is voluntary, but students were given attention for meaningful improvement (Goldman, Cohen, \& Sheahan, 2008).Parents need to give freedom for their children to choose what activities they want to participate, but still need monitor on how their children spend their time (Adeyemo, 2010 ).

Participation in extracurricular activities included better grades, higher standardized test scores, a high level of education, regular school attendance and higher self-concepts (Wilson, 2009). Students should give little time to the activities and their social aspects and other activities (Al-Ansari, Al-Harbi, Aziz, AbdelSalam, Tantawi, \& Elrefae, 2015 ).

\section{Research Method}

\subsection{Design}

This research study used descriptive correlation to the variables to determine the relationship between parental communication and students participation in school activities.

\subsection{Environment}

This study was conducted in Jagobiao National High School Department in the second floor and the new building of Senior High School which located in Jagobiao, Mandaue City. The building of Grade 11 Senior High School offers academic track namely Accountancy and Business Management (ABM), General Academic Strand (GAS), Technical Vocational Learning (TVL) and Humanities and Social Sciences (STEM). The new building of Senior High School offers the academic track which are Humanities and Social Sciences (HUMSS), Accountancy and Business Management (ABM), General Academic Strand (GAS), and the 


\section{Macrothink

Grade 11 Science Technology Engineering Mathematics (STEM).

\subsection{Respondents}

The respondents were all Senior High School students particularly in Grade 11 and Grade 12. There were 16 males and 19 females for a total of 35 respondents in Grade 11 STEM. There were 19 males and 24 females for a total of 43 respondents in Grade 11 HUMSS. There were 6 males and 21 females for a total of 27 respondents in Grade 11 ABM. There were 8 males in Grade 11 TVL. There were 14 males and 26 females for a total of 40 respondents in Grade 11 GAS. There were 8 males and 15 females for a total of 23 respondents in Grade 12 GAS. There were 14 males and 31 females for a total of 45 respondents in Grade 12 HUMSS. There were 8 males and 21 females for a total of 29 respondents in Grade 12 ABM. Total respondents are 250 students.

\subsection{Data Gathering Procedure}

The researcher needs to ask permission from the adviser of Grade 11 and Grade 12 students of Jagobiao National High School. When it will be approved, the researcher will be allowed to conduct study. The respondents will be guided by questionnaire checklist guide. The data depends on the answer of the respondents. The gathering of information will be used to evaluate and process the whole study.

\subsection{Instrument}

The researcher used Questionnaire Checklist as a tool and guide in gathering data. The checklist is adopt by the internet the author are Dejana, T., Aleksandar, B., and Mejousek, M. A checklist is a list of items required, things to be done or points to be considered used as a reminder for the purpose of gathering information from respondents the first part of questionnaire is indicate to the parental communication and the second part is indicate to the students participation in school activities. The scoring is 1 Always, 2 Often, 3 Sometimes, 4 Never. 


\section{Data Analysis and Discussion}

Table 1. Levels of Parental Communication

\begin{tabular}{lll}
\hline Indicators & WM & Interpretation \\
\hline 1. I do something wrong with my parents & 2.33 & Sometimes \\
2. I talk with my parents about my problem. & 2.27 & Sometimes \\
3. I talk with my parents about my feelings. & 1.97 & Sometimes \\
4. I talk with my parents about my friends. & 2.62 & Often \\
5. My parents treat me as a equal family. & 3.24 & Often \\
6. My parents allow me to do anything. & 2.63 & Often \\
7. When I do something wrong my parents beat me. & 2.19 & Sometimes \\
8. When I do something wrong my parents talk me about my behavior. & 2.99 & Often \\
9. When I do something wrong my parents explain to me my mistake. & 2.93 & Often \\
10. When I do something wrong my parents punished me. & 2.31 & Sometimes \\
11. When I'm trouble, members of my family support each other. & 2.67 & Often \\
12. I believe I can tell my parents what I feel and think about things. & 2.50 & Sometimes \\
13. I can always count my parents help. & 2.57 & Often \\
14. It's difficult to talk with my parents about anything. & 2.51 & Often \\
15. In our family everyone can freely express his/her opinion and feelings & 2.66 & Often \\
Overall Weighted Mean & $\mathbf{2 . 5 6}$ & Often \\
\hline
\end{tabular}

SCALE: 1.00-1.75-(Never) 1.76-2.50- (Sometimes) 2.51-3.25- (Often) 3.26-4.00- (Always)

The table 1 presented that 15 of the indicators from the variable of Parental communication has the overall weighted mean of 2.56. And the weighted mean in the first table was interpreted as Often. And it has a highest weighted mean of 3.24, and the lowest weighted mean is 1.97. (Runcan, Constantineanu, \& Popa, 2012) The relationship between parents and children have an important relationship. (Zolten, \& Long 2006) The relationship between parents and children have an important relationship. (Eustice 2000) Parental communication can contribute aggressiveness relationships to their children.

Table 2. Parental Communication

Frequency of the Levels of Parental Communication

\begin{tabular}{lllll}
\hline & Frequency & Percent & Valid Percent & Cumulative Percent \\
\hline Seldom & 42 & 17.1 & 17.1 & 17.1 \\
Moderate & 169 & 69.0 & 69.0 & 86.1 \\
Always & 34 & 13.9 & 13.9 & 100.0 \\
Total & $\mathbf{2 4 5}$ & $\mathbf{1 0 0 . 0}$ & $\mathbf{1 0 0 . 0}$ & \\
\hline
\end{tabular}

SCALE: 1.00-1.75-(Never) 1.76-2.50- (Sometimes) 2.51-3.25-(Often) 3.26-4.00- (Always) 


\section{Macrothink}

Out of 245 respondents there are many students are moderated by the communication of their parents with the frequency of 169 . There are also students who have seldom communication by their parents that have a frequency of 42 . Furthermore, there are some students who always have a good communication to their parents. Teenagers who communicate better to their parents are less likely to engage in sexual activities (Karofsky, Zeng, \& Kosorok, 2001). When it comes family communication it is very helpful to us to communicate each other and it have a positive results of the family communication (Le Poire, 2019). Furthermore, Parental communication can contribute aggressiveness relationships to their children (Eustice, 2000).

Table 3. Levels of Students Participation in School Activities

\begin{tabular}{lll}
\hline Indicators & WM & Interpretation \\
\hline 1. I asked questions in class or contributed to class discussions. & 2.61 & Often \\
2. I worked with students on project during classes. & 2.76 & Often \\
3. I worked with classmates outside of class to prepare class assignments. & 2.60 & Often \\
4. I participated in a community based projects as part of a class regular course. & 2.50 & Sometimes \\
5. I made a class presentation. & 2.62 & Often \\
6. I came to class without completing assignments. & 2.49 & Sometimes \\
7. I prepared two or more drafts of a paper or assignments before turning it. & 2.38 & Sometimes \\
8. I tutored or teach other students (paid or voluntary) & 2.22 & Sometimes \\
9. I discussed ideas from reading or classes with the students. & 2.42 & Sometimes \\
10. I worked with faculty members on activities. & 2.23 & Sometimes \\
Overall Weighted Mean & $\mathbf{2 . 4 8}$ & Sometimes \\
\hline
\end{tabular}

SCALE: 1.00-1.75-(Never) 1.76-2.50- (Sometimes) 2.51-3.25- (Often) 3.26-4.00- (Always)

The table 2 presented that 10 of the indicators from the variable of Student Participation in school activities has the overall weighted mean of 2.48. And the weighted mean in the second table was interpreted as Sometimes and Often. And it has a highest weighted mean of 2.76 and 2.62, while the lowest weighted mean is 2.22. (Runcan, Constantineanu, \& Popa, 2012) The relationship between parents and children have an important relationship. (Zolten, \& Long 2006) The relationship between parents and children have an important relationship. (Eustice 2000) Parental communication can contribute aggressiveness relationships to their children. 
Table 4. Levels of Students Participation in School Activities

Frequency of the Levels of Student Participation

\begin{tabular}{lllll}
\hline & Frequency & Percent & Valid Percent & Cumulative Percent \\
\hline Not at all & 2 & .8 & .8 & .8 \\
Seldom & 23 & 9.4 & 9.4 & 10.2 \\
Moderate & 190 & 77.6 & 77.6 & 87.8 \\
Always & 30 & 12.2 & 12.2 & 100.0 \\
Total & $\mathbf{2 4 5}$ & $\mathbf{1 0 0 . 0}$ & $\mathbf{1 0 0 . 0}$ & \\
\hline
\end{tabular}

SCALE: 1.00-1.75-(Never) 1.76-2.50- (Sometimes) 2.51-3.25- (Often) 3.26-4.00- (Always)

Out of 245 respondents there are many students are moderated to participate the school activities with the frequency of 190 . There are also students who have always participate the school activities that have a frequency of 30. Furthermore, there are some students who seldom to participate and also there are some students are not at all like to participate the school activities. To help develop students skills and personalities so as to prepare them for more advanced levels through school-based activities (Petra, 2014). Participation of students in the classroom is an important part of the learning and teaclLearning is an immersive process involving participation of both lecturers and the students (Abdullah, Bakar \& Mahbob, 2012).

Table 5. Levels of Parental Communication and Student Participation Cross tabulation

Student Participation

\begin{tabular}{lllllll}
\hline & & Not at all & Seldom & Moderate & Always & Total \\
\hline \multirow{2}{*}{ Parental Communication } & Seldom & 0 & 10 & 30 & 2 & 42 \\
& Moderate & 2 & 13 & 137 & 17 & 169 \\
Total & Always & 0 & 0 & 23 & 11 & 34 \\
\hline
\end{tabular}

The table 5 presented a cross tabulation in parental communication and student participation in school activities. It was presented that the students are moderated by the communication of their parents to participate the school activities have a total of 169 and 190. Therefore, there are some students who always have a communication to participate the school activities has total of 30 and 34. While there are some students who seldom and not at all have a communication to participate the school activities. Participation in extracurricular activities included better grades, higher standardized test scores, a high level of education, regular school attendance and higher self-concepts (Wilson, 2009). Parents need to give freedom for their children to choose what activities they want to participate, but still need monitor on how 
their children spend their time (Adeyemo, 2010 ). Parental interaction in sport can have a huge impact on children, so a better understanding of this aim is required to produce the best developmental results that sport can achieve (Grimm, Dunn, Hall, \& Dorsch, 2017).

Table 6. Levels of Parental Communication and Students Participation in School Activities

\begin{tabular}{llll} 
Chi-Square Tests & \multicolumn{3}{l}{} \\
\hline & Value & df & Asymp. Sig. (2-sided) \\
\hline Pearson Chi-Square & $28.623 \mathrm{a}$ & 6 & .000 \\
Likelihood Ratio & 26.756 & 6 & .000 \\
Linear-by-Linear Association & 19.274 & 1 & .000 \\
N of Valid Cases & 245 & & \\
\hline
\end{tabular}

A. 6 cells $(50.0 \%)$ have expected count less than 5 . The minimum expected count is .28 .

The table shows that the significant value is .000 (i. e., $\mathrm{p}=.000$ ) which is less than the alpha (0.05).The decision is reject Ho, there is a significant association between the two variables parental communication and student's participation in school activities. Through student participation in school is necessary have a meaningful learning (Simovska, 2004). The teacher must create helpful learning situation so that the students will actively participate (Abdullah, Bakar, \& Mahbob, 2012). The communication and relationship of parents and their children are the most important of individuals life to show affection, make sense of their life experience and create communication surroundings (Horstman, Hays, \& Maliski, 2016) .

\section{Findings}

The level of student's participation in school activities has an impact on their academic performance; students who participate the school activities is get more highest score and grades especially they are more motivated having a communication with their parents than the students who is not participating the school activities and they are not have a communication with their parents. But base on the interpreted data the overall weighted mean of student participation is two point forty eight and it is interpreted as Often.

The level of parental communication to their children give an encouragement and the students is more motivated to participate the school activities. The parents give more attention and time to communicate the students are more likely to participate. But base on the interpreted data the overall weighted of parental communication is two point fifty sixth and it is interpreted as Sometimes and Often.

Parents communication and students participation in school activities are correlated with each other. It implies that students participation in school activities and parents communication has a relation to affect the academic performance of the students and have the possibility that the student is more motivated and more encouraged to participate the school activities by having the communication of their parents. It indicates that those students who participate continue of being what you have now and those students who is not participating need to have an 
effective communication. But base on the result of the study parents communication and students participation in school activities are significant to each other. So it is concluded that students participation in school activities and parental communication have a relationship to each other.

\section{Conclusion}

Parents who do not have effective communication with their children, fail to develop the confidence, students are not encouraged and motivated to participate the school activities than the parents who have effective communication with their children. Parental communication is related to the students who participate the school activities. Some of the students is depending on how there parents interact and communicate them. Most of the students in senior high school of Jagobiao National High School most of them are more motivated and they have an encouragement to participate the school activities because of communication to their students. Parental communication is correlated to students participation in school activities.

\section{Recommendation}

Based on the findings of the study, students who have an effective communication to their parents have an impact towards participation in school activities. Besides, their parents can help them to motivate and encourage to participate. They can make their parents proud on what they achieve because of the communication that they give.

Parents can encourage their children in different ways to participate the school activities. Through communication, they can motivate and encourage their children to participate.

Teachers can also guide and motivate their students to participate the school activities and help them to realize that participation is important. Through the communication of the teacher to their students the children will have a confidence to participate.

\section{References}

Abdullah, M, Y., Bakar, N, R., \& Mahbob, M, H., (2012a). Students Participation in Classroom: What motivate them to Speak up? Procedia-Social and Behavioral Sciences, 51(2012), 516-522. https://doi.org/10.1016/j.sbspro.2012.08.199

Abdullah, M, Y., Bakar, N, R., \& Mahbob, M, H., (2012b). The dynamics of Student Participation in School Activities: Observation on level and forms of Participation. Procedia-Social and Behavioral Sciences, 59(2012), 61-70. https://doi.org/10.1016/j.sbspro.2012.09.246

Adeyemo, S. (2010). The Relationship between Students Participation in School Based Extracurricular Activities and their Achievement in Physics. International Journal of Science and Technology Education Research, 1(6), 111-117. Retrieved from https://academicjournals.org/journal/IJSTER/article-full-text-pdf/B349AF92387

Al-Ansari, A., Al-Harbi, F., AbdelAziz, W., AbdelSalam, M., El Tantawi, M., \& Elrefae, I. (2015). Factors affecting Student Participation in extra-curricular Activities: A Comparison 
between two Middle Eastern Dental Schools. The Saudi Dental Journal, 28, 36-43 https://doi.org/10.1016/j.sdentj.2015.05.004

Aziz, f., Quraishi, U., \& Kazi. (2018). Factors behind Classroom Participation of Secondary School Students (A Gender Based Analysis). Universal Journal of Education Research, 6(2), 211-217. https://doi.org/10.13189/ujer.2018.060201

Bergmark, U., \& Westman, S. (2018). Student Participation within Teacher Education: Emphasizing democratic values, Engagement and Learning for a future Profession. Higher Education Research and Development, 37(7), 1352-1365. https://doi.org/10.1080/07294360.2018.1484708

Davidson, T., \& Cardemil, E. (2009). Parent-child Communication and Parental Involvement in Latino Adolescents. Journal of Early Adolescents, 9(1), 99-121. https://doi.org/10.1177/0272431608324480

Debele, E, T., \& Kelbisa, E, M. (2017). The Role of active methods for classroom participation: The case of first year students od sociology in Samara University. IOSR Journal of Humanities and Social Sciences, 22(7), 11-18. Retrieved from https://www.researchgate.net/publication/331037369_The_Role_of_active_learning_methods _for_classroom_participation_The_case_of_first_year_students_of_sociology_in_Samara_U niversity

Dejana, T., Aleksandar, B., \& Mejousek, M. (1997). Pscicothema-Parent-child-communication. University of Zagreb, Faculty of Defectology, 9, 547-554. Retrieved from https;//www.psicothema.com/psicotheme.asp?id=26

Eustice, K. (2000). Aggressive communication, Parental Communication, and Sibling Communication. Eastern Illinois University Charleston. Retrieved from https://thekeep.eiu.edu/cgi/viewcontent.cgi?referer=https://www.google.com/\&httpsredir=1\& article $=2639 \&$ context $=$ theses

Goldman, R., Cohen, A., \& Sheahan F. (2008). Using Seminar Blogs to Enhance Student Participation and Learning Public Health School Classes. American Journal of Public Health, 98(9), 1658-1663. https://doi.org/10.2105/AJPH.2008.133694

Griebler, U., Rojatz, D., Simovska, V., \& Forster, R. (2017). Effects of Student Participation in School Health Promotion: A Systematic Review. Health Promotion International, 32, 195-206. https://doi.org/10.1093/heapro/dat090

Grimm, M., Dunn, R., Hall, E., \& Dorsch, T. (2017). Parent-child communication in Sport: Integrating theory into research. Journal of Amateur Sport. Retrieved from https://www.researchgate.net/publication/321364694_Parent-child_communication_in_sport_ Bridging_the_gap_between_theory_and_research/link/5a26d2090f7e9b71dd0c8148/downloa d

Grogan, K., Henrich, C., \& Malikina, M. (2014). Student Engagement in After-School Programs, Academic Skills, and Social Competence among Elementary School Students. 
Hindawi Publishing Corporation Child Development Research, 2014(498506), 9. https://doi.org/10.1155/2014/498506

Hortsman, H., Hays, A., \& Maliski. (2016). Parent-Child Interaction. Oxford Research Encyclopedia Communication, $1-30$ https://doi.org/10.1093/acrefore/9780190228613.013.278

Irwin, S. (2002). The Effects of a Parent-Child Communication Activity on the Worries of Siblings of Children with Autism. Illinois Wesleyan University Digital Commons@ @ IWU. Retrieved from http://digitalcommons.iwu.edu/psych_honproj7

Karofsky, P., Zeng, L., \& Kosorok M., (2001). Relationship between Adolescents-Parental Communication and Initiation of first intercourse by adolescents. Journal of Adolescent Health, 28(1), 41-45. https://doi.org/10.1016/S1054-139X(00)00156-7

Koerner, A., \& Schrodt, P. (2014). An Introduction to the Special Issue on Family Communication Patterns Theory. Journal of Family Communication, 14, 1-15 https://doi.org/10.1080/15267431.2013.857328

Koerner, K., \& Fitzpatrick, M. (2002). Family Communication Patterns Theory: A Social Cognitive Approach. Communication Yearbook, 26, 37-69. https://doi.org/10.1207/s15567419cy2601_2

Lachance, A., Benton, C., \& Klein, B, S. (2007). The School Based Activities Model: A Promising Alternative to Professional Development Schools. Teacher Education Quarterly, Summer, 95-109. Retrieved from https:/files.eric.ed.gov/fulltext/EJ795176.pdf

Laursen. B. (2004). Parent-child Communication during Adolescents. Department of Psychology Florida Atlantic University, 16, 334-344. Retrieved from https://www.researchgate.net/publication/256444591

Marcell, A., Ford, C., Pleck, J., \& Sonenstein, F., (2007). Masculine Beliefs, Parental Communication, and Male Adolescents Health Care Use. Pediatrics Official Journal of the American Academy of Pediatrics, 119-966. https://doi.org/10.1542/peds.2006-1683

Merkley, D., Schimdt, D., \& Dirksen, C., (2006). Enhancing Parents-Teacher Communication using Technology a Reading: Improvement Clinic Example. Contemporary Issues in Technology and Teacher Education, 6(1), 11-12. Retrieved from https://www.citejournal.org/volume-6/issue-1-de/English-language-art/enhancing-parent-teac her-communication-technology-reading-improvements-clinic-example/

Petra, F. (2014). School-Based Activities: A Tool for Student Development. American International Journal of Contemporary Research, 4(3), 64-71. Retrieved from https://www.researchgate.net./publication/261619676

Runcan, P, L., Constantineanu, C., Ielics, B., \& Popa, D. (2012). The Role of Communication in the Parent-Child Interaction. Procedia-Social and Behavioral Sciences, 46, 904-908. https://doi.org/10.1016/j.sbspro.2012.05.221 


\section{Macrothink Institute ${ }^{\text {TM }}$}

Simovska, V. (2004). Student Participation: A Democratic Education Perspective-Experience from the Health-Promoting Schools in Macedonia. Health Education Research, 19(2), 198-207. https://doi.org/10.1093/her/cyg024

Thorson, A., \& Horstman, H. (2016). Family Communication Patterns and Emerging Adult Consumer Outcomes: Revisiting the Consumer Socialization Model. Western Journal of Communication, 1-24.

Wilson, N. (2009). Impact of Extracurricular Activities on Students. University of Wisconsin-Stout, 1-31. Retrieved from https://www2.uwstout.edu/content/lib/thesis/2009/2009wilsonn.pdf

Zolten, K., \& Long. (2006). Parent and child communication, Department of Pediatrics. University of Arkons for Medical Sciences Artwork by Scoot Spider. Retrieved from httsps://www.researchgate.net/publication/24860147astudyofparentsparticipation in the high school administration and its effect on school activities

\section{Glossary}

Parental communication: is a relationship between the parents and their children. It is very important for parents to be able to communicate openly and effectively with their children. Open, effective communication benefits not only the children, but also every member of the family.

Student participation: is an involvement themselves in class. That might be evaluated in student participation discussion.

School activities: applies to wide range of skill based games, strategies and interactive activities that support students educational development. Common activities include Arts Organizations (Choir, Chinese Club, Miss UN, Miss PE and etc.), Academic Competition (Quiz bee, Poster making and Slogan).

\section{Appendix}

Appendix 1.Survey Questionnaire for Mindset and Stress

\section{TOOL: CHECKLIST}

Direction: Put a check for each statement, there are possible responses and on a scale from $1-4$, where 1 is never and 4 is always. Remember you can choose only one answer for each statement.

\section{4-Always, 3-Often, 2-Sometimes, 1-Never}

\section{Part I. Parental Communication}

\begin{tabular}{lllll}
\hline Indicators: & 1 & 2 & 3 & 4 \\
\hline 1. I do something wrong with my parents. & & & & \\
2. I talk with my parents about my problem. & & & & \\
\hline
\end{tabular}


3. I talk with my parents about my feelings.

4. I talk with my parents about my friends.

5. My parents treat me as equal family.

6. My parents allows me to do anything.

7. When I do something wrong my parents beats me.

8 . When I do something wrong my parents talks with me about my behaviour.

9. When I do something wrong my parents explain to me my mistake.

10. When I do something wrong my parents punished me.

11. When I'm trouble, members of my family support each other.

12. I believe a can tell my parents what I feel and think about things.

13. I can always count my parents help.

14. Its difficult to talk with my parents about anything.

15. In our family everyone can freely express his/her opinion and feelings.

retrieved from : https;//www.psicothema.com/psicotheme.asp?id=26

\section{Part II. Student Participation in School Activities}

\begin{tabular}{l}
\hline Indicators: \\
\hline 1. I asked questions in class or contributed to class discussions. \\
2. I worked with students on projects during class. \\
3. I worked with classmates outside of class to prepare class assignments. \\
4. I participated in a community based projects as part of a class regular course. \\
5. I made a class presentation. \\
6. I came to class without completing assignments. \\
7. I prepared two or more drafts of a paper or assignments before turning it. \\
8. I tutored or teach other students (paid or voluntary) \\
9. I discussed ideas from reading or classes with the students. \\
10. I worked with faculty members on activities.
\end{tabular}

retrieved from: https;//www.psicothema.com/psicotheme.asp?id=26

\section{Copyrights}

Copyright for this article is retained by the author(s), with first publication rights granted to the journal.

This is an open-access article distributed under the terms and conditions of the Creative Commons Attribution license (http://creativecommons.org/licenses/by/4.0/). 